\title{
A SAJÁtos NeVELÉSi IGÉNY JELENLÉte A PANNON EGYETEMEN
}

\author{
Horváth H. AtTila ${ }^{*}$ - Tóth-MÁRhoffer MÁrta ** \\ * a Pannon Egyetem \\ egyetemi docense \\ hha@almos.vein.hu \\ ** a Pannon Egyetem \\ egyetemi tanársegédje \\ martimarhoff@gmail.hu
}

A Pannon Egyetemen hosszú évek óta kiemelt figyelmet kap a sajátos nevelési igény kérdése. A speciális szükséglettel élők iránti befogadó / pozitív attitüd egyaránt jelen van a tanárképzés programjában, más karok munkájában, az érintett hallgatók mindennapjait érintö ügyek, helyzetek kezelésében. Írásunkban bemutatjuk, hogyan jelenik meg e szemlélet a gyakorlatban és a leendö pedagógusok felkészitésében és az egyetemi élet különbözö területein.

\section{Bevezetés}

A többségi társadalom müködésének az egyik fokméröje lehet, hogy miként tekint a különböző kisebbségekre, hogyan tematizálja és kezeli az e téren felmerülö problémákat, megoldandó feladatokat. Az Európai Unióban rendkívül erős a társadalmi elkötelezettség a befogadó társadalom létrehozására (Halász, 2004). Kulcskérdés, hogy a gyermekek szocializációjában jelentős szerepet játszó pedagógusok milyen attitüddel viszonyulnak a sajátos nevelési igényeket támasztó gyermekekhez; mennyire képesek a befogadó szemlélet kialakítására, alkalmazására; mennyire tudják a kulturális sokszínűségből adódó másság mellett az egyéni képességekből eredő másság tolerálására, természetesnek vételére nevelni a felnövekvő generációt.

Magyarországon is erős a törekvés a mássággal élő gyermekek, fiatalok integrált nevelésére. A szemlélet alapja az esélynövelés, esélyteremtés. Az integrált nevelés szakít a korábbi megközelítéssel, amely a gyermekben, föként a hibás képességekben kereste a sikertelenség okát, és a gyermeket a környezetével egységben szemlélve a körülményeket kívánja olyanná tenni, amelyben a gyermek fejlödése optimális lehet. Az integrált nevelés támogatásával a közoktatás új igényeket támasztott a pedagógusokkal szemben: a multikulturális és a gyógypedagógiai ismeretek jelenléte elengedhetetlenné vált a pedagógusképzésben.

Írásunkban azt mutatjuk be, hogyan alakítjuk, fejlesztjük a pedagógusképzés során a sajátos nevelési igényü tanulók befogadó neveléséhez szükséges kompe- 
tenciákat. Ebben a munkában fontos szerepe van annak a ténynek, hogy az egyetemi élet más területén is ezzel a szemlélettel, attitüddel találkoznak a hallgatók. Igyekszünk természetes tapasztalatszerzést biztosítani a hallgatóknak, ahol életszerü tevékenységek során mehet végbe a tanulás. Nagyban építünk a csoportfolyamatokban rejlő tanulás lehetőségeire, a saját viszonyulások sajátélményü megtapasztalására, mely az attitüdök finomhangolásának alapja lehet, $\mathrm{s}$ megfelelő motivációt biztosíthat az elméleti ismeretek elsajátítására. Arra törekszünk, hogy kialakuljon a hallgatóknak az a felkészültsége, amelyet használható, gyakorlatban is értékes tudásnak tekintenek, s képesek legyenek pozitív érzelmekkel fordulni a sajátos nevelési igényü gyermekek, fiatalok felé.

\section{Sajátos szükségletü hallgatók az egyetemi életben}

A Pannon Egyetem (korábban Veszprémi Egyetem) mindig azt elvet vallotta, hogy lehetőséget biztosít a fogyatékossággal élők számára az egyetemi tanulmányokhoz. Ennek az elvnek az érvényesítését segítették a nagyszabású akadálymentesítési átalakítások, felújítások. Jóllehet még mindig nem teljesen akadálymentes a veszprémi kampusz, de a hallgatókra való odafigyelés és a jó szervezés következtében mégis az az érzése lehet mindenkinek, mintha az lenne. Az érintett hallgatókkal folytatott szóbeli és írásos kommunikációban megerősítést nyert, hogy akadálymentesnek érzik az intézmény épületeit és a tanulási környezetet. Álljon itt egy mozgássérült hallgató véleménye: ,Az egyetemen eddig eltöltött évek alatt csakis pozitív tapasztalatokról számolhatok be. Mind a tanárok, mind a hallgatók részéröl megtapasztalhattam az elfogadást és a pozitív hozzáállást már az elsö évben. Mindent elkövettek, hogy gördülékenyen folytathassam tanulmányaimat, a szaktanszék már elsö héten felkinálta a fénymásolás lehetöségét, amivel az elöadás anyagait másolhattam le, illetve hallgatótársaim is készségesen rendelkezésemre bocsátották jegyzeteiket, megkönnyitve a tanulási folyamatot. Ugyanezt a pozitivv viszonyulást tapasztaltam más tanszékek oktatóival kapcsolatban is, hiszen a zh-k szóban történö teljesitésére mindig adtak lehetöséget, hogy ne kelljen szenvednem az irással. [...] Az egyetem további munkatársai részéröl is csak pozitív tapasztalataim vannak, itt kiemelném az ügyintézöket, akikhez bármikor fordulhatok, ha problémám akad. A kurzusok többsége során nem igen került elö a fogyatékossággal élök témája [...] csak a pedagógiával kapcsolatos tárgyak keretében. [...] Az órarendem eddig mindig a lehetö legkedvezöbben volt összeállitva - még ha nem is hozzám igazitották - még Ba-n is [...] Jelenleg a legjobb elosztásban vannak az óráim, mivel egy épületben vagyok egész héten, így nem kell vándorolnom egyik helyröl a másikra."

Azt gondoljuk, hogy a sajátos nevelési igényü gyerekkel folytatott pedagógiai munkára való felkészülésben nagy szerepe van annak is, hogy a leendő tanárok az egyetemi évek alatt együtt tanulnak, együtt élnek fogyatékos hallgatókkal. Így egyfelől megtapasztalják saját maguk hozzáállását a fogyatékkal élő társaikhoz, s mivel 
hosszú távú dologról van szó, ez idő alatt alkalmuk nyílik finomítani saját attitűdjükön, különösen, ha az idegenkedö vagy éppen sajnálkozó. Másfelől betekintést nyernek a sajátos nevelési igényhez kapcsolódó mindennapi problémákba oktatási, szervezési és technikai vonatkozások terén is. Új dimenzióba kerülnek előttük a roszszul látható prezentációk, vagy a nem megfelelően felszerelt termekben a rosszul hallható előadások, vagy éppen az akadálymentesítés hiányai. A hallgatók azzal szembesülnek, hogy azok a dolgok, amelyek számukra kényelmetlenségként, zavaró, bosszantó tényezőként szerepelnek, sérült társaiknak akár a teljes kizáródást jelenthetik az oktatás folyamatából.

Érdemes jelezni, hogy ha a sajátos szükségletü hallgatók szempontjából beszélünk az oktatásban felmerülő nehézségekről, akkor még a jól látható, olvasható prezentációk esetén is vannak olyan hallgatók, akik ez esetben is nehezen megoldható problémákkal szembesülnek, ők a diszlexiások. Néhány könnyen betartható szempont érvényesítésével azonban az előadók számukra is jól feldolgozható anyagot állíthatnak össze:

- Vázlatos összefoglalással kezdjünk!

- Rövid sorok.

- Kerülni a túlzottan fehér hátteret.

- Balra zárt szöveg.

- Ahol lehet, szedjük pontokba a szöveget!

- Kerüljük a passzív szerkezetet!

- Használjunk illusztrációkat! (Gyarmathy, 2010.)

Azért is fontos a pedagógusképzés pedagógiájával külön is foglalkozni, és visszatérően megszervezni a képzők képzése programokat, hogy az olyan speciális tudások, mint a sajátos szükségletủ diákok nevelése, oktatása az egyetemi oktatók széles körében is - ne csak a tanárképzés területén - ismert és alkalmazott legyen. Az e területen lévő speciális tudás gazdagítását szolgálta az a jeltolmács képzés, amelyet a Siketek és Nagyothallók Országos Szövetsége Veszprém megyei szervezetével együttmüködve valósított meg a Tanárképző Központ. A képzésen hallgatók és oktatók is részt vettek, és vizsgát is tehettek a jelnyelv ismeretéből.

Egy érdekes találkozási forma a sajátos nevelési igénnyel a Pannon Egyetemen a TanulÓ Galéria, amely a helyszínt adó Tanárképző Központ $(\mathrm{O})$ épületéről kapta a nevét. Két éve Poór Zoltán kezdeményezésére indult útjára ez a rendezvénysorozat, amelynek keretében a megye nevelési intézményei - óvodától középiskoláig - kapnak lehetőséget a bemutatkozásra. A tanévben havi gyakorisággal újulnak meg a tárlók, a programban rendszeresen helyet kapnak a speciális iskolák munkái is. (Például: Bárczi Gusztáv Általános Iskola, Speciális Szakiskola; Kozmutza Flóra Általános Iskola Készségfejlesztő Speciális Szakiskola és Kollégium; Molnár Gábor Óvoda, Általános Iskola, Speciális Szakiskola és Egységes Gyógypedagógiai Módszertani Intézmény.) A tanulók müsorral fogadják a látogatókat a megnyitón, amely a gyerekeknek, a tanároknak és a vendégeknek egyaránt kellemes ün- 
nepi és örömteli perceket jelent. A kiállítások szervezésébe tanár szakos hallgatóink is aktív részt vállalnak, segítik a pedagógusokat és a gyermekeket, bepillanthatnak az iskola munkájába, a tanórán kívüli pedagógiai tevékenységbe és megtapasztalhatják a rendezvény légkörét. Alkalmi feladatokba is igyekszünk bekapcsolódni, például a Víz világnapján a Pannon Egyetem Limnológia Tanszékének oktatóival együttmúködve a Kozmutza Flóra Általános Iskola Készségfejlesztő Speciális Szakiskola és Kollégiumban tartottak tanár szakos hallgatóink élménydús délutánt a gyermekeknek.

A Müszaki Informatikai Karon mérnök informatikus, programtervező informatikus és gazdaságinformatikus szakokon nincs kimondottan olyan tantárgy, ami az oktatással vagy speciális nevelést igénylö problémákkal foglalkozik. Azonban van egy szabadon választható kurzus Sikné Lányi Cecilia vezetésével, „Felhasználói interfészek tervezése" címmel, amelynek keretében pár héten keresztül bepillantást nyernek a hallgatók a fogyatékos embereknek való szoftver, illetve web-felület tervezésének kérdéseibe, e felhasználók mindennapi életének problémáiba és szükségleteibe. Talán ennek hatására (is) jelentkeznek a hallgatók olyan témájú szakdolgozatokra és diplomamunkákra, melyeknek keretében fogyatékos emberek életvitelét, rehabilitációját segítő, illetve fogyatékos gyerekek oktatását segítő szoftverek készülnek.

Az elmúlt másfél évtizedben közel 70 ilyen témájú diplomamunka született. E munkák során mindig kikérik az adott fogyatékossággal foglalkozó szakemberek véleményét. Sőt a hallgatók látogatást tesznek egy-egy speciális iskolában, fejlesztői csoportban, rehabilitációs intézetben, ahol szorosan együttmüködnek a leendö felhasználókkal, hogy a munkájuk végén valóban jól használható szoftver szülessen. Ezek a látogatások motiválják a hallgatókat, mert az első ijedtség, félelem, szorongás után rájönnek mennyire hasznos és humános célú leendő diplomamunkájuk. A fogyatékossággal élők számára készült szoftvereket nagyon nagy örömmel és megelégedettséggel használják nemcsak Magyarországon, hanem külföldön is (Sík Lányi és Lányi, 2003; Sík Lányi et. al., 2005). A nagyon sikeres diplomamunkákból nemzetközi publikációk is születnek (Sík Lányi et. al., 2006, 2012). Sőt büszkén állíthatjuk, hogy a publikációk kapcsán szerte a világból kapunk leveleket, hogy küldjük el, vagy tegyük letölthetővé a fejlesztett szoftvereket, játékokat. Ennek egyik oka az, hogy a szoftver/játékfejlesztő cégek nem gondolnak a fogyatékossággal élő emberekre. Így a Pannon Egyetemen az e téren készült és készülő diplomamunkák hiánypótlónak számítanak.

Az egyetemen a Speciális Szükségletü Hallgatókat Segítö Bizottság koordinálja a különböző karokon tanuló érintett hallgatók segítését. A Bizottság egyetemi koordinátora megalakulása óta a Tanárképző Központ valamely oktatója. A törvényi lehetőségeket kihasználva a Bizottság támogatja a központi keretből a hallgatókat igényeiknek megfelelően: speciális segédeszköz biztosításával (elektromos kerekesszék), tananyag hozzáféréssel (fénymásolás, diktafon kölcsönzés stb.), az utazás 
megkönnyítésével (taxicsekk), tanszercsomag adásával, laptop kölcsönzéssel segítettük a diákokat. Sikerült elérni, hogy a karok oktatói természetesnek veszik az esetenkénti hosszabb felkészülési időt, a szóbeli-írásbeli vizsgák közül a hallgató számára a megfelelöbb biztosítását.

\section{A sajátos nevelési igény problémája a tanárképzés tartalmában}

Céljaink megvalósítása érdekében önálló tárgyakként és más tárgyakba beépítve is megjelennek az integráció és az inklúzió kérdései. A tanárképzés folyamatában az is célunk, hogy megfelelö gyógypedagógiai alapismereteket nyújtsunk a tanárjelöltek számára. Legyenek jártasak a leggyakrabban előforduló problémák területén, ismerjék a segítő eljárások elvét, a társintézményeket, váljanak képessé bizonyos zavarok felismerésére. Tekintsenek empatikus szemlélettel, befogadó attitüddel a sajátos nevelési igényü tanulókra. legyenek képesek segítő módszerek, eljárások alkalmazására, programok kialakítására.

A felkészítést már az alapképzés során megkezdjük a tanári mesterszakra bemenetet segítö úgynevezett pedagógiai-pszichológiai elökészitö blokk keretében. E blokkot azoknak a hallgatóknak kínáljuk, akik érdeklődnek a tanárképzés iránt. A nagyon eltérő pályamotivációval rendelkező hallgatók körében e blokk tárgyaiban részben a pedagóguspályához való viszony, a motiváció, az érzelmek, a nem tudatos nézetek, sémák átgondolása zajlik, s e folyamatba szándékosan építünk be a sajátos nevelési igényt támasztó gyermekekkel, fiatalokkal kapcsolatos elemeket is.

A személyes pedagógiai nézetek átgondolása során szót ejtünk a normalitás, abnormalitás, a fejleszthetőség, a nevelhetőség kérdésköréröl, s foglalkozunk azzal a témával is, hogy mikor és miként ismerhető meg, diagnosztizálható egy gyermek sajátos nevelési igénye, „fogyatékossága”. Az utóbbival kapcsolatban számos tévhit él a hallgatókban, amelyeknek előhozása, pontosítása, megértése fontos a pozitív attitűd kialakítása érdekében. Provokatív keretet adhat erre a Tau Ceti III. játék ${ }^{1}$, de beszélgetésvezetéssel vagy irodalmi szemelvény alkalmazásával is megközelíthető a témakör.

Kommunikációt fejlesztő játékok során gyakran alkalmazunk olyan játékokat, mely során valamely csatorna alkalmazásában akadályokat állítunk a hallgatók elé. Ez nem csupán arra alkalmas, hogy saját kommunikációs ügyességét megtapasztalja, hanem arra is lehetőséget biztosít, hogy empátiája segítségével a sérült emberek korlátait is felismerje. Tapasztalatot szerezhetnek a segítségnyújtás és a rászorultság érzéseiről is. Bunkerjáték során a sztereotípiák, elő́téletek átdolgozása is zajlik, szembesülnek azzal, hogy mennyire sematikusan ítéljük meg embertársainkat.

\footnotetext{
${ }^{1}$ A játékosok a Tau Ceti III bolygóra költöző emberiség társas együttélésének szabályait alkotják meg. Provokáló mondata: ,...ha egy újszülöttről kiderül, hogy nem lesz képes elérni a felnőttkori önellátás szintjét, fájdalommentesen véget kell vetni az életének" (Rudas, 1990, 242-243. o.)
} 
A mesterképzés során több tárgyban is megjelennek olyan tartalmak, melyek segítik a hallgatókat ismereteik gyógypedagógia irányú bővítésében. A teljesség igénye nélkül mutatunk be néhány példát. Fejlödés- és személyiséglélektan kurzus során szó esik a fejlődés eltéréseirôl, a méhen belüli fejlődés során fellépő ártalmakról, s megismerik a hallgatók a perinatális történések fejlődésben betöltött jelentőségét. A tanulók személyiségének megismerését célzó kurzus során szó esik a tanulási zavarok tünettanáról, a korai és iskolai felismerés lehetőségeiről és szürőeljárásairól. Az iskolai mentálhigiéné elmélete és gyakorlata keretében is foglalkozunk a pszichopedagógia érvényességi körébe is sorolható érzelmi és magatartási zavarokkal, a deviáns viselkedésformákkal. Pedagógiai szociálpszichológia keretében tárgyaljuk az iskolában megjelenő elöítéletek, sztereotípiák körét, attitüdöket. Saját élményủ gyakorlat során sor kerülhet a társadalmi távolság mérésére a különböző társadalmi csoportok között, amelyek közé a különböző fogyatékossággal élők csoportjai is felvehetöek.

A mesterképzés során hospitálás keretében végeznek megfigyeléseket óvodákban, iskolákban hallgatóink. Megfigyelési szempontjaik közé emeltük a sajátos nevelési igényű gyermekek, tanulók jellemzőinek megfigyelését is. Fókuszálunk a differenciálás módjára, a szociális kapcsolatok alakulására, megnyilvánulására, a segítés, az empátia kifejeződésére a többi gyermek részéről. A hospitálások során szegregált intézményekbe is ellátogatunk, ahol a hallgatók súlyosabb értelmi fogyatékossággal küzdő gyermekekkel is találkozhatnak, s kapcsolatot alakíthatnak ki velük. A hallgatóknak legtöbbször ez az első találkozása értelmileg sérült gyermekekkel, s ez a nagyban befolyásolja a valós tapasztalat az addigi sematikus elképzeléseket.

A Pedagógiai helyzetgyakorlat és a Szociális kompetenciák fejlesztése kurzus egyaránt alkalmat adnak szituációs játékok alkalmazására, amely gyakran hívja elő a hallgatók reflexióit is, amelyek még élménnyel telítettebbé teszik a vizsgált kérdéseket. Így kerültek felszínre mozgássérült hallgatók problémái a közlekedésben. Az egyik hallgató mesélte, hogy a buszsoför nem engedte az első ajtónál leszállni. Kénytelen volt a hátsó ajtóhoz menni, holott amúgy is nehezen jár, de az ülések közötti szük folyósón még nagyobb gondot okozott számára. Az ilyen játékok során az is előjön, hogy ha elviekben tudják is, hogyan viselkedjenek egy-egy érintett társukkal, a gyakorlatban ez nem mindig sikerül.

Van, hogy példaértékü történeteket mesélnek középiskolás tapasztalataikról. Az egyik kerekesszékhez kötött hallgató az osztályának musical előadásában kapott fontos szerepet. A darabot színre vivő énektanár természetesnek fogadtatta el a szereplökkel és a nézőkkel a helyzetet, és olyan koreográfiát tervezett, amelyben mindig akadt egy olyan szereplö, aki magától értetődő módon tartotta a mikrofont a tolószékes társa számára.

Önálló tárgyként jelenik meg a mesterképzésben a Gyógypedagógiai alapismeretek. A hallgatók feladatai közé tartozik a szakirodalmi tájékozódás, szakirodalmi jegyzék készítése. Minden hallgató a félév végére a megadott témák közül 
egyet választva egy esszét készít. Az esszé témája lehet saját ötlet alapján készülő is, pl. egy tánccal aktívan foglalkozó hallgató a táncterápia lehetőségeit gondolta át sérült gyermekek fejlesztésében. Kötelező feladat egy megfigyelés teljesítése megadott szempontok alapján, célunk, hogy a hallgató felismerje a sérülésspecifikus sajátosságokat, azonosítani tudjon jellemző megnyilvánulásokat. Tájékozódást kérünk a gyógypedagógia történetben is, három hazai és három nemzetközileg kiemelkedő személy bemutatása a hallgatók feladata. A kurzus során alkalmazzuk a vita, a beszélgetés, az előadás, a forráselemzés, az önálló kutatás, a megfigyelés módszereit, csoportban, párban, vagy egyénileg dolgozva. Számos alkalommal élünk a kép erejével, mozifilm-részleteket illesztünk az órák menetébe. Kiváló források lehetnek pl. a Csillagok szerelmese, A bal lábam, Esöember, A nevem, Sam, A király beszéde, Elefántember, Egy kisebb isten gyermekei, Zongoralecke címü filmek (Billédi, 2008). További filmfelvételeket is segítségül hívhatunk például a Baltazár színház előadásairól, ,No arms, no legs, no worries”, speciális olimpia felvételei, értelmi fogyatékosok müvészeti találkozójának felvételei, korai fejlesztés felvételei jelenhetnek meg az órákon.

Projektpedagógia az integráció szolgálatában tárgy keretében az integráció folyamatának segítése szempontjából kerül alkalmazásra a projektmódszer (Martonné, 2006). Kiváló tervek készültek a hallgatók részéről, melyekből levelező tagozatos, másoddiplomás hallgatóink többet meg is valósítottak.

Szakdolgozataink témakiírásai közt is szerepelnek lehetőségként az SNI-vel kapcsolatos kutatási témák. Mivel egyre több iskola érintett az integrált nevelésben, főleg levelezős, másoddiplomás képzésben részt vevő hallgatóink körében népszerü e témák választása. Egy TÁMOP pályázat keretében tanárképzős hallgatóinknak lehetőséget tudtunk biztosítani az integrált nevelés megfigyelésére az egyik partneriskolánkban, Söjtörön.

\section{Összefoglalás}

Az SNI témakörben született diplomamunkák is bizonyítják, hogy hallgatóink érdeklődőek e terület iránt, és érzékenységükről, kreativitásukról is számot adnak. Igyekszünk mindent megtenni azért, hogy ez a szemlélet és felkészültség széles körben jellemezze az oktatókat és a hallgatókat egyaránt.

Fontosnak tartjuk, hogy a Pannon Egyetemen olyan tanulási környezetet biztosítsunk, amelyben a - nemcsak a tanárképzésben lévő - hallgatók sajátélményü tanulás során is betekintést nyerhetnek az sajátos szükségletü társaik mindennapjaiba. A tanárképzés kurzusai úgy épülnek fel, hogy mind az előkészítő szakaszban, mind a mesterképzés során a hallgatók találkoznak az SNI problematikájával, és kifejezetten gyógypedagógiai ismereteket is elsajátítanak. Célirányosan építünk a csoportfolyamatokban rejlö tanulás lehetőségeire, a saját viszonyulások megtapasztalására, mely az attitüdök finom hangolásának alapja lehet. Változatos tevékenykedtetéssel 
arra törekszünk, hogy a tanárjelöltjeink kellő ismeretekkel rendelkezve pozitív érzelmekkel forduljanak a sajátos nevelési igényü gyermekek, fiatalok felé.

Reméljük, hogy az egyetemi lehetőségek és tapasztalatok hatására tanár szakos hallgatóink képessé válnak a közoktatásba kerülve az integrált nevelés és a tényleges inklúzió megvalósítására.

\section{Irodalom}

Billédi Katalin (2008): Inkluzív nevelés - Elöitélet-mentes attitüd - tolerancia. Educatio Társadalmi Szolgáltató Közhasznú Társaság, Budapest.

Gyarmathy Éva (2010): Diszlexia felsöfokon. Magyar diszlexia oldalak. Letöltés ideje: 2012. 05. 21. http://www.diszlexia.hu/

Halász Gábor (2004): A sajátos nevelési igényű gyermekek oktatása: európai politikák és hazai kihívások. Új Pedagógiai Szemle, 2. sz. 28-38.

Martonné Tamás Márta (szerk., 2006): Integráció és inklúzió - Fejlesztő módszerek a közoktatásban. Trefort Kiadó, Budapest.

Rudas János (1990): Delphi örökösei. Gondolat Könyvkiadó, Budapest.

Sik Lányi, C., Lányi, Zs. (2003): Multimedia Program for Training of Vision of Children. Journal of Information Technology Education, 279-290. Letöltés ideje: 2012. 05. 18. http://www.jite.org/documents/Vol2/v2p279-290-28.pdf

Sik Lányi, C., Szabó, J., Páll, A., Pataky, I. (2005): Computer-Controlled Cognitive Diagnostics and Rehabilitation Method for Stroke Patients. ERCIM News ERCIM EEIG, April, pp. 53-54. Letöltés ideje: 2012. 05. 18.

http://www.ercim.org/publication/Ercim_News/enw61/lanyi.html

Sik Lányi, C., Geiszt, Z., Károlyi, P., Tilinger, Á., Magyar, V. (2006): Virtual Reality in special needs early education. The International Journal of Virtual Reality, No 4. 55-68. Letöltés ideje: 2012. 05. 18. http://www.ijvr.org/issues/issue4/7.pdf

Sik Lányi, C., Brown, D., Standen, P, Lewis, J., Butkute, V. (2012): Results of user interface evaluation of serious games for students with intellectual disability. Acta Polytechnica Hungarica, No. 1. 225-245. Letöltés ideje: 2012. 05. 18.

http://www.uni-obuda.hu/journal/Issue33.htm

Smythe, I. (ed., 2002): Provision and use of information and communication technology with adultdyslexic students in university in Europe. WDP, Cardiff. 